\section{'NC-Davie' and 'NC-Duplin' Pickling Cucumber Hybrids}

Todd C. Wehner

Department of Horticultural Science, North Carolina State University, Raleigh, NC 27695-7609

Additional index words. Cucumis sativus, germplasm, processing cucumber, vegetable breeding

Four pickling (processing) cucumber inbreds (NC-54, NC-55, NC-56, and NC-57) and two pickling cucumber hybrids ('NCDavie' and 'NC-Duplin'), were developed at North Carolina State University. As with most cucumber cultivars released from N.C. State, 'NC-Davie' and 'NC-Duplin' were named for places around the state. 'NC-Davie' is the $\mathrm{F}_{1}$ of NC-54 $\times$ NC-55, and 'NC-Duplin' is the $\mathrm{F}_{1}$ of NC-56 $\times$ NC- 57 . The four inbreds have been self-pollinated past the $\mathrm{S}_{12}$ generation, and were developed from the North Carolina Elite Determinate Pickling (NCEDP) cucumber population. The NCEDP population was developed by 1) crossing elite hybrids and inbreds with NCSU M 21 dwarf-determinate inbred in 1983;2) intercrossing the determinate $\mathrm{F}_{2}$ with determinate hybrids and inbreds; and 3 ) intercrossing the $F_{1}$ to form a population for use in recurrent selection. Selection methods were developed that optimized gain for yield and other traits (Wehner, 1989). Selection in the NCEDP population was for fruit shape, and total, marketable and early yield in the spring season, as well as for resistance to foliar fungal diseases in the summer season. The main diseases in the summer were anthracnose [Colletotrichum orbiculare (Berk. and Curt.) Arx] and gummy stem blight [Didymella bryoniae (Auersw.) Rehm]. In addition to yield, earliness, quality and disease resistance, the cucumber families were selected for production of sufficient seeds to plant the test and intercross plots, rapid seed germination and emergence, rapid vine growth and flowering, and proper fruit type.

\section{Origin}

The NC-54, NC-55, NC-56, and NC-57 inbreds, and 'NC-Davie' and 'NC-Duplin' hybrid pickling cucumbers were developed from crosses of dwarf-determinate NCSU M 21 with elite pickling cucumbers having high yield, earliness, fruit quality, and disease resistance (Fig. 1). NCSU inbred M 21 was used to introduce the dwarf-determinate plant type into elite inbreds and hybrids. All had high disease resistance and American pickling type fruit. Half the inbreds used were gynoecious and half were monoecious. In addition, Gy 2

Received for publication 30 Dec. 2004. Accepted for publication 3 Mar. 2005. The use of trade names in this publication does not imply endorsement by the NCARS of the products named, or criticism of similar ones not mentioned. Thanks to Tammy L. Ellington for technical assistance. and 'Clinton' had small seedcell, Gy 4 had high yield, Harris $4 \mathrm{~J}_{73} \mathrm{~F}_{1}$ had good general performance, and WI 2757 had seedling resistance to 7 diseases. The inbreds were crossed to make elite gynoecious hybrids, the hybrids crossed with NCSUM 21, the F s self pollinated, and the $\mathrm{F}_{2}$ selected for determinate type (Fig. 1). The determinate $\mathrm{F}_{2}$ were backcrossed to the elite gynoecious hybrids, the $\mathrm{BC}_{1}$ self pollinated, and 64 plots of the $\mathrm{BC}_{1} \mathrm{~S}_{1}$ intercrossed in a field isolation block with 24 plots of determinate $\mathrm{M}$
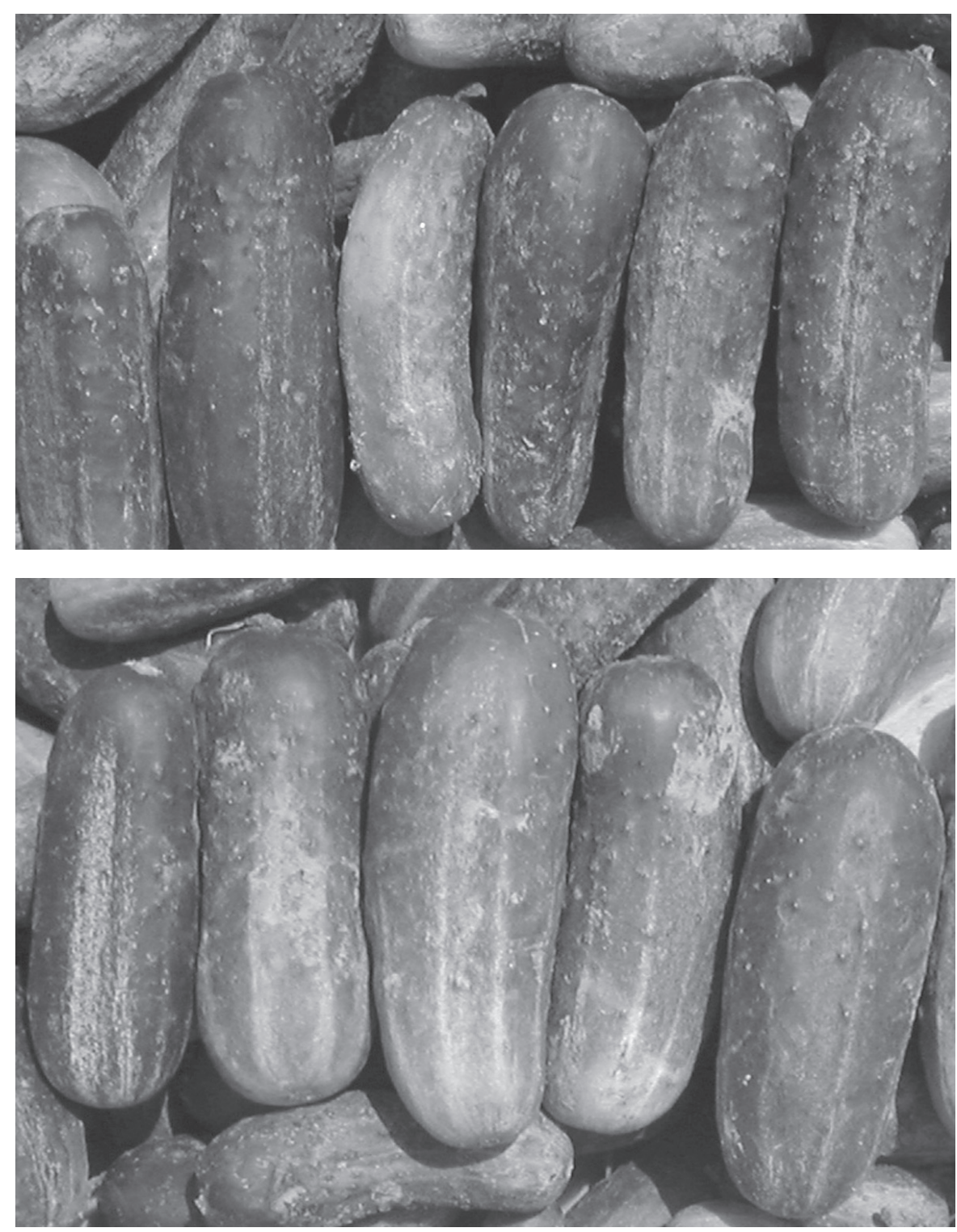

Fig. 2. Fruit of 'NC-Davie' (top) and 'NC-Duplin' (bottom) hybrid pickling cucumbers.
21, M27, 'Castlepik 2012', and Castlehy 2014. That intercross block was used as the cycle 0 of the North Carolina Elite Determinate Pickle (NCEDP) population. The NCEDP population was then improved for disease resistance, yield, earliness, and fruit quality through 9 cycles of recurrent selection.

Populations were improved by testing in the spring season followed by intercrossing the best families in isolation blocks in the summer season. Once-over harvest was simulated by spraying the foliage with paraquat (1,1'-dimethyl-4,4'-bipyridinium ion) at 0.6 $\mathrm{kg} \cdot \mathrm{ha}^{-1}$ when the checks had approximately $10 \%$ oversized fruit by number (Wehner et al., 1984). Oversized fruit exceeded $51 \mathrm{~mm}$ in diameter. Half-sib families were evaluated for 5 traits: total yield (number of fruit per plot), early yield (number of oversized fruit per plot), marketable yield (total yield minus crooked and nubbin fruit), fruit shape rating $(1=$ poor to $9=$ excellent), and a simple weighted index (Wehner, 1982). The simple weighted index was calculated as SWI $=0.2($ total yield $) / 2+$ 0.3 (early yield $)+0.2(\%$ marketable yield $) / 10$ 
+0.3 (fruit shape). Total yield was divided by 2 and percentage marketable yield was divided by 10 to give them the same range (1 to 9) as the other traits. Each trait was then given a weight $(20 \%$ or $30 \%)$ to reflect its importance in the breeding program. SWI was weighted $(70 \%)$ toward yield traits, but with significant emphasis on quality since shape rating $(30 \%)$ is related to fruit appearance, and marketable yield $(20 \%)$ accounts for crooked and nubbin fruit.

Inbred lines were evaluated in trials for yield, earliness, fruit quality, and disease resistance using optimized trialing methods (Wehner, 1987). Recommended cultural practices (summarized by Schultheis, 1990) were used throughout the experiments. Monoecious inbred 'Sumter' was planted in field border rows and end tiers as a pollenizer, and to provide border competition for the trial. Irrigation was applied when needed for a total of 25 to $40 \mathrm{~mm}$ per week (including rainfall). Fertilizer was incorporated at a rate of $90-39-74 \mathrm{~kg} \cdot \mathrm{ha}^{-1}$ $(\mathrm{N}-\mathrm{P}-\mathrm{K})$ before planting, with an additional $34 \mathrm{~kg} / \mathrm{ha} \mathrm{N}$ applied at the vine-tip-over (4 to 6 true leaf) stage. Herbicide [Curbit, ethalfluralin, $N$-ethyl- $N$-(2-methyl-2-propenyl)2,6-dinitro-4-(trifluoromethyl)benzenamine] and insecticide (Sevin, carbaryl, 1-Naphthyl $\mathrm{N}$-methylcarbamate) were applied at recommended rates.

In the Spring 1996 greenhouse, 384 half sib families from the NCEDP C9 population were tested in the seedling stage for resistance to scab and anthracnose, and the most resistant plants transplanted for testing with powdery mildew. The most resistant 346 plants were self pollinated to produce S1 lines. The 346 $\mathrm{S} 1$ lines were then tested in the seedling stage in the greenhouse for resistance to scab and anthracnose, and the most resistant plants transplanted for testing with powdery mildew. Simultaneously, the 346 S1 lines were tested in the field for gynoecy, determinate habit, yield, earliness, and fruit quality. The lines with the best performance were then planted in the greenhouse to advance the materials to S9 inbred lines.

Table 1. Horticultural performance (yield, earliness, quality, and disease resistance) of new semi-determinate pickling cucumber hybrids (NC-Davie and NC-

Duplin) compared with standard cultivars (all others). Data are summarized over three replications and six harvests for two crop production seasons (spring and summer) at the Horticultural Crops Research Station near Clinton, N.C., for 2001 through 2003.

\begin{tabular}{|c|c|c|c|c|c|c|c|c|c|}
\hline Population & $\begin{array}{c}\text { Total } \\
\text { yield } \\
\left(\mathrm{Mg} \cdot \mathrm{ha}^{-1}\right)\end{array}$ & $\begin{array}{c}\text { Early } \\
\text { yield } \\
(\%)\end{array}$ & $\begin{array}{c}\text { Cull } \\
\text { yield } \\
(\%)\end{array}$ & $\begin{array}{c}\text { Fruit } \\
\text { shape }^{\mathrm{x}}\end{array}$ & $\begin{array}{l}\text { Fruit } \\
\text { color }^{\mathrm{w}}\end{array}$ & $\begin{array}{l}\text { Seed } \\
\text { cell }^{\mathrm{v}}\end{array}$ & $\begin{array}{c}\text { Firmness } \\
\text { (lb) }\end{array}$ & $\begin{array}{l}\text { Length } \\
\text { to diam } \\
\text { ratio }\end{array}$ & $\begin{array}{c}\text { Anthracnose } \\
\text { rating }^{\mathrm{u}}\end{array}$ \\
\hline \multicolumn{10}{|l|}{$2001^{t}$} \\
\hline NC-Davie & 32.2 & 70 & 18 & 7.9 & 7.5 & 4.8 & 14 & 2.9 & 3.3 \\
\hline NC-Duplin & 29.4 & 63 & 19 & 7.8 & 7.4 & 4.5 & 14 & 3.1 & 2.5 \\
\hline Napoleon & 34.5 & 73 & 26 & 7.3 & 8.3 & 6.3 & 13 & 3.3 & 5.3 \\
\hline $\operatorname{LSD}(5 \%)$ & 8.8 & 12 & 12 & 0.8 & 0.6 & 0.8 & 2 & 0.2 & 1.3 \\
\hline \multicolumn{10}{|l|}{ Spring 2002} \\
\hline NC-Davie & 24.3 & 42 & 28 & 6.3 & 7.3 & 4.7 & 17 & 3.1 & 2 \\
\hline NC-Duplin & 20.4 & 41 & 28 & 6.7 & 7.7 & 5.3 & 18 & 3.0 & 2 \\
\hline M 21 & 12.4 & 18 & 25 & 7.3 & 6.7 & 6.7 & 15 & 3.6 & 1 \\
\hline Napoleon & 12.6 & 21 & 25 & 6.0 & 8.0 & 6.5 & 16 & 3.2 & 1 \\
\hline Calypso & 13.1 & 17 & 28 & 6.7 & 6.0 & 6.0 & 18 & 2.9 & 2 \\
\hline Raleigh & 18.5 & 50 & 33 & 6.7 & 7.3 & 5.3 & 17 & 3.4 & 2 \\
\hline Johnston & 26.2 & 38 & 32 & 8.0 & 8.0 & 6.7 & 18 & 3.5 & 2 \\
\hline Wis. SMR 18 & 7.8 & 9 & 41 & 5.0 & 3.7 & 3.7 & 17 & 3.0 & 6 \\
\hline $\operatorname{LSD}(5 \%)$ & 12.7 & 14 & 17 & 1.7 & 0.9 & 1.9 & 2 & 0.4 & 2 \\
\hline \multicolumn{10}{|c|}{ Summer 2002 (hot, dry conditions) } \\
\hline NC-Davie & 8.4 & 54 & 44 & 5.7 & 6.7 & 5.7 & 14 & 3.1 & 3 \\
\hline NC-Duplin & 6.6 & 50 & 43 & 6.3 & 7.0 & 4.7 & 14 & 2.9 & 4 \\
\hline M 21 & 3.0 & 42 & 45 & 6.0 & 6.7 & 5.7 & 12 & 3.4 & 4 \\
\hline Napoleon & 6.4 & 54 & 35 & 5.3 & 7.8 & 5.0 & 14 & 3.1 & 4 \\
\hline Calypso & 8.1 & 61 & 32 & 6.0 & 6.0 & 5.0 & 14 & 3.0 & 4 \\
\hline Raleigh & 8.1 & 62 & 33 & 5.7 & 6.7 & 5.7 & 14 & 3.3 & 3 \\
\hline Johnston & 5.1 & 53 & 46 & 6.3 & 6.7 & 7.3 & 14 & 3.2 & 3 \\
\hline Wis. SMR 18 & 6.2 & 64 & 39 & 6.0 & 4.3 & 4.3 & 12 & 3.3 & 7 \\
\hline LSD (5\%) & 3.7 & 17 & 18 & 1.5 & 1.5 & 2.2 & 3 & 0.5 & 1 \\
\hline \multicolumn{10}{|l|}{ Spring 2003} \\
\hline NC-Davie & 24.7 & 42 & 17 & 8.0 & 6.3 & 5.0 & 14 & 3.0 & 1 \\
\hline NC-Duplin & 24.8 & 45 & 20 & 6.7 & 7.0 & 4.7 & 15 & 3.2 & 1 \\
\hline M 21 & 23.6 & 48 & 21 & 6.7 & 6.7 & 7.0 & 13 & 3.7 & 2 \\
\hline Napoleon & 24.9 & 47 & 13 & 7.7 & 8.7 & 6.3 & 13 & 3.0 & 2 \\
\hline Calypso & 28.3 & 45 & 19 & 7.0 & 5.0 & 6.0 & 15 & 3.1 & 2 \\
\hline Raleigh & 29.4 & 57 & 15 & 7.7 & 7.3 & 6.3 & 14 & 3.2 & 2 \\
\hline Johnston & 29.0 & 51 & 18 & 6.7 & 7.0 & 7.0 & 15 & 3.9 & 1 \\
\hline Wis. SMR 18 & 22.9 & 38 & 32 & 7.0 & 3.7 & 5.0 & 15 & 3.0 & 6 \\
\hline $\operatorname{LSD}(5 \%)$ & 7.0 & 10 & 8 & 1.5 & 1.5 & 1.6 & 3 & 0.5 & 1 \\
\hline \multicolumn{10}{|l|}{ Summer 2003} \\
\hline NC-Davie & 22.2 & 62 & 32 & 7.3 & 6.0 & 4.7 & 16 & 2.9 & 3 \\
\hline NC-Duplin & 20.6 & 59 & 20 & 7.3 & 6.7 & 6.0 & 15 & 3.1 & 2 \\
\hline M 21 & 19.1 & 54 & 18 & 7.0 & 7.3 & 6.3 & 15 & 3.8 & 3 \\
\hline Napoleon & 22.4 & 61 & 12 & 7.7 & 9.0 & 8.0 & 14 & 2.9 & 3 \\
\hline Calypso & 22.0 & 67 & 22 & 7.0 & 5.7 & 6.7 & 17 & 3.0 & 3 \\
\hline Raleigh & 25.0 & 71 & 20 & 7.0 & 6.3 & 5.3 & 16 & 2.9 & 3 \\
\hline Johnston & 25.5 & 70 & 17 & 6.0 & 8.0 & 7.0 & 15 & 3.5 & 2 \\
\hline Wis. SMR 18 & 16.5 & 54 & 30 & 6.0 & 4.0 & 3.7 & 15 & 2.9 & 6 \\
\hline LSD $(5 \%)$ & 12.2 & 13 & 15 & 1.4 & 1.2 & 1.7 & 3 & 0.4 & 1 \\
\hline
\end{tabular}

${ }^{\mathrm{z}}$ Weight of all grades including oversized and cull fruit.

ypercent of the six-harvest yield that occurred in the first two harvests.

${ }^{x}$ Fruit shape was rated 1 to 9 ( 1 to $3=$ pointed, crooked, constricted; 4 to $6=$ tapered, curved, necked; 7 to $9=$ blocky, straight, cylindrical).

${ }^{\mathrm{w}}$ Fruit color rated 1 to 9 ( 1 to $3=$ light green, 4 to $6=$ medium green, 7 to $9=$ dark green).

'Seedcell size rated 1 to 9 ( 1 to $3=$ large, 4 to $6=$ medium, 7 to $9=$ small).

"Disease rating taken 1 week after the final harvest, and rated 0 to $9(0=$ none, 1 to $2=$ trace, 3 to $4=$ slight, 5 to $6=$ moderate, 7 to $8=$ severe, $9=$ dead $)$.

${ }^{t}$ Mean of four environments: spring, summer, Clinton field 1 , Clinton field 2.

${ }^{\text {s} A l l ~ f o u r ~ c u l t i v a r s ~ h a d ~ a ~ d w a r f-d e t e r m i n a t e ~ r a t i n g ~ o f ~} 4$ to 5 ( 1 to $3=$ dwarf, 4 to $6=$ medium dwarf, 7 to $9=$ tall), and a gynoecious rating of 5 to 6 ( 1 to $3=$ androecious, 4 to $6=$ monoecious, 7 to $9=$ gynoecious). 
Table 2.

\begin{tabular}{|c|c|c|}
\hline Year & Season & Location-Event \\
\hline$\overline{1983}$ & Fall & $\begin{array}{l}\text { Greenhouse-M21×(Gy2×Clinton }), \text { M21×(Gy4×M21), M21×Harris 4J73, } \\
\text { M21×WI2757 }\end{array}$ \\
\hline 1984 & Spring & Greenhouse- $\mathrm{F}_{1}$ (self all) \\
\hline 1984 & Fall & Greenhouse $-F_{2}$ (backcross elite parents with $\operatorname{det} F_{2}$ ) \\
\hline 1985 & Spring & Greenhouse-BC (self all) \\
\hline 1985 & Summer & $\begin{array}{l}\text { Field-Cycle } 0 \text { of NCEDP population (isolation intercross of } 64 \text { plots of } \mathrm{BC}_{1} \mathrm{~S}_{1} \\
\text { with } 24 \text { plots of M21, M27, Castlepik2012, Castlehy2014) }\end{array}$ \\
\hline $1986-92$ & --- & Field population improvement, with cycles $\mathrm{C}_{1}-\mathrm{C}_{7}$ \\
\hline 1993 & --- & --- \\
\hline 1994-95 & --- & Field population improvement, with cycles $\mathrm{C}_{8}-\mathrm{C}_{9}$ \\
\hline 1996 & Spring & Greenhouse- 384 HS (test scab, anth, PM, self 1 plant each) \\
\hline 1996 & Summer & Greenhouse- $346 \mathrm{~S}_{1}$ (test scab, anth, PM, self 1 plant each) \\
\hline 1996 & Summer & Field- $352 \mathrm{~S}_{1}$ (test gyn, det, yield, earliness, quality) \\
\hline 1996 & Fall & Greenhouse $-36 \mathrm{~S}_{2}$ (test scab, anth, PM, self 1 plant each) \\
\hline 1997 & Spring & Greenhouse- $-22 \mathrm{~S}_{3}^{2}$ (test scab, anth, PM, self 1 plant each) \\
\hline 1997 & Summer & Greenhouse- $140 \mathrm{~S}_{4}$ (test scab, anth, PM, self 1 plant each) \\
\hline 1997 & Summer & Field-140 $\mathrm{S}_{4}$ (test gyn, det, yield, earliness, quality) \\
\hline 1997 & Fall & Greenhouse- $-30 \mathrm{~S}_{5}$ (test scab, anth, PM, self 1 plant each) \\
\hline 1998 & Spring & Greenhouse- $57 \mathrm{~S}_{6}$ (test scab, anth, PM, self 1 plant each) \\
\hline 1998 & Summer & Greenhouse- $-96 \mathrm{~S}_{7}^{\circ}$ (test scab, anth, PM, self 1 plant each) \\
\hline 1998 & Summer & Field-27 S (test gyn, det, yield, earliness, quality) \\
\hline 1999 & Spring & Greenhouse $-42 \mathrm{~S}_{8}$ (test scab, anth, PM, self 1 plant each) \\
\hline 1999 & Summer & Field-137 S (test gyn, det, yield, earliness, quality) \\
\hline 1999 & Fall & Greenhouse $-12 \mathrm{~S}_{9}$ (self, cross 6 gyn $\times 6$ mon $)$ \\
\hline 2000 & Spring & Greenhouse $-12 \mathrm{~S}_{10}$ (self, cross 6 gyn $\times 6$ mon $)$ \\
\hline 2000 & Summer & Greenhouse- $-37 \mathrm{~S}_{11}^{10}$ (self 10 gyn, 27 mon) \\
\hline 2000 & Summer & Field-36 $\mathrm{F}_{1}$ (test gyn, det, yield, earliness, quality) \\
\hline 2000 & Fall & Greenhouse- $-15 \mathrm{~S}_{10}$ (make 15 inbreds, 13 hybrids) \\
\hline 2001 & Fall & Greenhouse- $6 \mathrm{~S}_{11}$ (make 6 inbreds, 3 hybrids) \\
\hline 2002 & Spring & Greenhouse- $6 \mathrm{~S}_{12}$ (make 4 inbreds, 2 hybrids) \\
\hline
\end{tabular}

In 1999, 12 hybrids were tested in the field using the best 6 gynoecious inbreds as female parents in crosses with the best 6 monoecious inbreds. Hybrids and inbreds were tested in the field for gynoecy, determinate habit, yield, earliness, and fruit quality. Inbreds of the hybrids with the best performance were then planted in the greenhouse to advance the materials to $\mathrm{S} 10$ inbred lines. The process was repeated in 2000 . Finally, the top three hybrids were then put into the cooperative trials for 2001, 2002, and 2003 (Table 1).

Trials were run in the spring and summer production seasons using a randomized complete block design. Check cultivars (Napoleon and M21 in 2001, then adding Calypso, Raleigh, Johnston, and Wisconsin SMR 18 in 2002 and 2003) were chosen to represent an elite gynoecious hybrid and a determinate monoecious inbred that performed well over the years. Plots were harvested six times (twice weekly). Data were summarized over 3 replications, and 6 harvests for 2 crop production seasons (spring, summer) for 3 years $(2001,2002,2003)$ at the Horticultural Crops Research Station near Clinton, NC.

Data from the performance trials were presented for 9 major horticultural traits (Table 1). Total yield was the weight of marketable grades, oversized, and cull fruit summed over six harvests. Early yield was the total weight for the first two harvests. Percentage culls was the weight of crooked and nubbin fruit relative to total fruit weight. The three major fruit quality traits presented were shape, color, and seedcell size. Fruit shape was rated 1 to 9 (1 the vegetative growth stage. NC-54 and NC56 have dwarf-determinate plant type, with gynoecious sex expression. NC-55 and NC-57 have tall-indeterminate plant type, with monoecious sex expression. All four inbreds produce numerous flowers beginning about $30 \mathrm{~d}$ after planting. Hybrids 'NC-Davie' and 'NC-Duplin' are monoecious (similar to 'Napoleon'), but with fewer pistillate flowers than 'Calypso', 'Raleigh', and 'Johnston' and more than NCSU M 21 and 'Wis. SMR 18'.

Fruit color for NC-54, NC-55, NC-56, and NC-57 inbreds, and 'NC-Davie' and 'NC-Duplin' hybrid pickling cucumbers is mottled, and medium- to dark-green, with lighter color at the blossom end. Fruit have few, large tubercles (warts), and are white spined. Fruit seedcell size of 'NC-Davie' and 'NC-Duplin' is medium (subjective rating of 5 to 6 vs. 6 to 7 for the checks, where 1 is large and 9 is small).

'NC-Davie' and 'NC-Duplin' are resistant to the major disease problems in the southeastern U.S., ranked in importance by St. Amand and Wehner (1991). They are resistant to anthracnose (Colletotrichum orbiculare (Berk. \& Mont.) Arx), powdery mildew (Sphaerotheca fuliginea (Schlechtend.:Fr.) Pollacci), and scab (Cladosporium cucumerinum Ellis \& Arth.). In addition to having semi-determinate habit for easy fruit harvest, 'NC-Davie' and 'NC-Duplin' were better than (or at least as good as) the gynoecious hybrid checks for all traits relating to yield, earliness, fruit quality, and disease resistance (Table 1). and cylindrical the fruit in a plot were (Strefeler and Wehner, 1986). Fruit color was rated 1 to 9 ( 1 to 3 = light green, 4 to $6=$ medium green, 7 to $9=$ dark green). Seedcell size was rated 1 to $9(1$ to $3=$ large, 4 to $6=$ medium, 7 to $9=$ small). Firmness was the amount of force $(\mathrm{N})$ required to punch into the fruit exocarp (skin) and mesocarp (flesh) with an $8 \mathrm{~mm}$ diameter tester(McCormick Fruit Tech, Yakima, Wash.). Anthracnose damage to the foliage was rated one week after the 6 th harvest $(0=$ none, 1 to $2=$ trace, 3 to $4=$ slight, 5 to $6=$ moderate, 7 to $8=$ severe, $9=$ dead). Anthracnose was naturally occurring in the trials since the spring trials were not sprayed with fungicides, and all trials had overhead irrigation to encourage disease spread.

\section{Description}

The NC-54, NC-55, NC-56, and NC-57 inbreds, and 'NC-Davie' and 'NC-Duplin' hybrid pickling cucumbers have excellent horticultural characteristics, suitable for use by the processing industry in the U.S. The inbreds and hybrids have medium-sized seeds, with rapid germination and emergence from either cool or warm soil. Vines have semi-determinate growth habit, some lateral branching, and normal-sized, very dark-green leaves, with the crinkled surface characteristic of the determinate plant type. Plants are vigorous, with rapid growth, and flowers and fruit develop early in

\section{Availability}

Seeds of the inbreds and hybrids are available to interested plant breeders who sign an intellectual property agreement. 'NC-Davie' and its parental inbreds NC-54 and NC-55 were licensed exclusively to Zeraim Gedera in 2004.

\section{Literature Cited}

Schultheis, J.R. 1990. Pickling cucumbers. N.C. State Ag. Ext. Hort. Info. Lfit. 14-A.

St. Amand, P.C. and T.C. Wehner. 1991. Crop loss to 14 diseases in cucumber in North Carolina for 1983 to 1988. Cucurbit Genet. Coop. Rpt. 14:15-17.

Strefeler, M.S. and T.C. Wehner. 1986. Estimates of heritabilities and genetic variances of three yield and five quality traits in three fresh-market cucumber populations. J. Amer. Soc. Hort. Sci. 111:599-605. trials and segregating populations. Cucurbit Genet. Coop. Rpt. 5:18-20.

Wehner,T.C. 1987. Efficient methods for testing vegetable cultivars. HortScience 22:1220-1223.

Wehner, T.C. 1989. Breeding for improved yield in cucumber, p. 323-359. In: J. Janick (ed.). Plant breeding reviews. vol. 6 .

Wehner, T.C., T.J. Monaco, and A.R. Bonanno. 1984. Chemical defoliation of cucumber vines for simulation of once-over harvest in small-plot yield trials. HortScience 19:671-673.
Wehner, T.C. 1982. Weighted selection indices for 